\title{
New directions in cellular therapy of cancer: a summary of the summit on cellular therapy for cancer
}

\author{
David F Stroncek ${ }^{1 *}$, Carolina Berger ${ }^{2}$, Martin A Cheever ${ }^{3}$, Richard W Childs ${ }^{4}$, Mark E Dudley ${ }^{5}$, Peter Flynn ${ }^{6}$, \\ Luca Gattinoni ${ }^{5}$, James R Heath ${ }^{7}$, Michael Kalos ${ }^{8}$, Francesco M Marincola ${ }^{1,9}$, Jeffrey S Miller ${ }^{10}$, \\ Gustavo Mostoslavsky ${ }^{11}$, Daniel J Powell Jr ${ }^{8}$, Mahendra Rao ${ }^{12}$, Nicholas P Restifo ${ }^{5}$, Steven A Rosenberg ${ }^{5}$, \\ John O'Shea ${ }^{13}$ and Cornelis JM Melief ${ }^{14}$
}

\begin{abstract}
A summit on cellular therapy for cancer discussed and presented advances related to the use of adoptive cellular therapy for melanoma and other cancers. The summit revealed that this field is advancing rapidly. Conventional cellular therapies, such as tumor infiltrating lymphocytes (TIL), are becoming more effective and more available. Gene therapy is becoming an important tool in adoptive cell therapy. Lymphocytes are being engineered to express high affinity T cell receptors (TCRs), chimeric antibody-T cell receptors (CARs) and cytokines. T cell subsets with more naïve and stem cell-like characteristics have been shown in pre-clinical models to be more effective than unselected populations and it is now possible to reprogram T cells and to produce $T$ cells with stem cell characteristics. In the future, combinations of adoptive transfer of $T$ cells and specific vaccination against the cognate antigen can be envisaged to further enhance the effectiveness of these therapies.
\end{abstract}

\section{Background}

A summit on cellular therapy for cancer was held on November 1 and 2, 2011 at the NIH in Bethesda, Maryland. Advances related to the use of adoptive cellular therapy for melanoma and other cancers were presented and discussed and are summarized in this review.

\section{Tumor infiltrating lymphocytes (TIL)}

Treatment of melanoma with tumor infiltrating lymphocyte (TIL) cells of high functional avidity has been improved by treating patients with lymphocyte reducing chemotherapy prior to the administration of the TIL cells. Preconditioning the TIL recipient with non-myeloablative chemotherapy has resulted in a objective clinical response rate of $49 \%$ with $13 \%$ complete responses and preconditioning with non-myeloablative chemotherapy plus 12 Gy total body irradiation (TBI) further improved objective clinical response rate to $72 \%$ with $40 \%$ complete responses [1].

\footnotetext{
* Correspondence: dstroncek@cc.nih.gov

'Department of Transfusion Medicine, Clinical Center, NIH, Bethesda, USA Full list of author information is available at the end of the article
}

Several advancements associated with manufacture of TIL have been made and as a result TIL production has become more practical. Traditionally, initial TIL cultures were screened for reactivity to tumor antigens and only the reactive cultures were selectively expanded. Many cell processing laboratories are no longer screening initial TIL colonies for tumor-reactive cells, rather, they are expanding all isolated TIL cells based on the initial finding that nearly $80 \%$ of TILs possess autologous tumor reactivity [2] This has reduced the duration of time that TIL spend in culture and as a result these cells are known as "young" TIL. Clinical studies are evaluating whether that young TIL are as effective as TIL produced using traditional methods [3].

TIL have been traditionally manufactured using tissue culture plates for initial culture and flasks and bags for rapid expansion protocols (REP). This process, however, results in large final culture volumes: 30 to 60 liters. These large volumes are associated with the use large quantities of media, cytokines, and additives. In addition, harvesting these large volumes is time consuming. In order to simplify and reduce the quantity of reagents

\section{C) Biomed Central}


and labor associated with TIL production, two new methods are being tested for TIL REP; bioreactors and gas permeable flasks. The WAVE bioreactor can be used for TIL REP [4]. The volume of the final TIL product is reduced by the WAVE bioreactor, but the WAVE requires the investment of capital and specialized staff training. The volume of media required for TIL REP can also be reduced by using gas permeable flasks [5]. The flasks are simple to use and do not require capital investment. In addition, gas permeable flasks can also be used for initial TIL culture.

The increased clinical effectiveness and improved production methods are leading to the more widespread use of TIL to treat patients with melanoma.

\section{Engineered T cells}

While TIL Therapy is effective, melanoma samples cannot be obtained for TIL production from all patients and, in some cases, TIL cannot be isolated from the resected tumor. Engineered $\mathrm{T}$ cells are being used increasingly for patients from whom TIL are not available. Two general approaches involving engineered $\mathrm{T}$ cells are being used clinically. Both involve the use of autologous peripheral blood $\mathrm{T}$ cells; one involves gene transfer of high affinity $\mathrm{T}$ cell receptors (TCR) and the other gene transfer of chimeric antibody- $\mathrm{T}$ cell receptors (CAR) [6].

Patients with melanoma have been treated with $\mathrm{T}$ cells engineered using recombinant retroviral vectors to express HLA-2 restricted high affinity $\mathrm{T}$ cell receptors (TCRs) specific for melanoma antigens MART-1 and gp100 $[7,8]$. While patients treated with these engineered autologous cells have had objective clinical responses, some patients have experienced autoimmune responses due to the destruction of normal melanocytes in the skin, eyes and ears [8]. Another adoptive cellular therapy approach utilizing engineered $\mathrm{T}$ cells involves the use of TCRs specific for cancer testis antigens that are expressed by fetal tissue and cancer, but not by adult cells, such as NY-ESO-1. NY-ESO-1 is expressed by 10 to $50 \%$ of metastatic melanomas, $80 \%$ of synovial cell sarcomas and breast, prostate, thyroid and ovarian cancers [6]. TCRs specific for NY-ESO-1 have been used to treat patients with melanoma and sarcoma and have resulted in objective clinical responses in 5 of 11 melanoma patients and 4 of 6 synovial sarcoma patients [9]. Protocols are also being developed that involve gene transfer of vectors encoding IL-12 and MAGE-A3 specific TCRs.

Another approach involves the transduction of autologous $\mathrm{T}$ cells to express CARs made up of the variable region a tumor specific antibody fused to an intracellular signaling domain capable of activating $\mathrm{T}$ cells. Typically, a CAR is comprised of an extracellular $\mathrm{scFv}$ portion of a monoclonal antibody and an intracellular CD3 zeta chain in tandem with a co-stimulatory signaling domain, such as CD28. In addition, some CARs include other stimulatory factors such as $4-1 \mathrm{BB}$ or OX40, alone or in combination with CD28 [6]. Since CARs have the specificity of a monoclonal antibody, they are not HLA restricted and they can be used to treat any patient whose tumor expresses the antigen to which the monoclonal antibody is directed. Autologous T cells engineered to express anti-CD19 CAR have been effective in treating patients with lymphoma and chronic lymphocytic leukemia (CLL) [10-13]. CD19 CAR T cell adoptive therapy has resulted in dramatic clinical responses which have been associated with in vivo expansion and long term persistence of the engineered $\mathrm{T}$ cells. Some patients have experienced tumor lysis syndrome and prolonged depletion of B cells is common.

A clinical protocol that uses the autologous $\mathrm{T}$ cells expressing CAR specific for the folate receptor -alpha (FR $\alpha$ )[14] is being developed by University of Pennsylvania investigators in cooperation with the National Cancer Institute (NCI) Cancer Immunotherapy Trial Network (CITN). FR $\alpha$ is over expressed on the surface of epithelial malignancies including ovarian, breast, renal, colorectal, lung, and other solid cancers, but its expression is limited on normal tissue. The protocol involves adoptive cell therapy with genetically engineered autologous $\mathrm{T}$ cells given to patients with ovarian cancer following lymphodepletion alone or followed by the administration of recombinant IL-7 and was rationalized by the established role for IL-7 in maintaining T cell memory and homeostasis, as well as initial observations by Powell et al. that transferred tumor antigenspecific $\mathrm{T}$ cells dramatically up-regulate the IL-7 receptor immediately after infusion [15].

\section{Reprogramming cells}

The reprogramming of adult cells in order to produce more primitive cells or stem cells is becoming an important part of cellular therapy of cancer. Adult cells can be reprogrammed to produce induced pluripotent stem cells (IPSC) which have properties similar to embryonic stem cells. Investigators are now working to reprogram $\mathrm{T}$ cells to produce "stem-like" $\mathrm{T}$ cells that are more effective in adoptive cell therapy.

\section{Induced pluripotent stem cells}

Methods to reprogram stem cells have improved greatly since Yamanaka first demonstrated that the transfer of 4 transcription factors, Oct4, Klf4, Sox2 and cMyc, into fibroblasts can produce IPSCs [16]. IPSCs differ in some respects from embryonic stem cells (ESCs) but these differences can be reduced by removing the transcription factor used for reprogramming. One method involves 
reprogramming using a single excisable lentivral vector containing all 4 transcription factors which allows for highly efficient reprogramming and IPSCs free of exogenous transgenes using from fresh and store blood samples [17-19]. Traditional culture of IPSCs involves the growth of cells on feeder cell layers or extracellular matrix derived from animals and the use of media supplemented with animal serum. Methods are being developed to produce and culture IPSC using xenogenic free materials and reagents which will improve the safety of these products. Companies are developing platforms for high throughput IPSC generation. These platforms also allow for cell maintenance and characterization.

\section{Reprogramming T cells}

Several studies have found that $\mathrm{T}$ cell phenotype affects their effectiveness for adoptive cell therapy. Comparison of TIL cells from patients responding to therapy and those that did not has found that clinical responses were associated with TIL that expressed co-stimulatory molecules CD27 and CD28, have longer telomeres and persist longer in vivo. Several investigators have been exploring methods to produce cytotoxic $\mathrm{T}$ cells which persist longer and are more effectively clinically [1]. Using CMV reactive T cells and a macaque model, Carolina Berger and Stan Riddell found that CMV-specific effector $\mathrm{CD}^{+} \mathrm{T}$ cell $\left(\mathrm{T}_{\mathrm{E}}\right)$ populations derived from central memory $\mathrm{T}$ cells $\left(\mathrm{T}_{\mathrm{CM}}\right)$ rather than effecter memory $\mathrm{T}$ cells $\left(\mathrm{T}_{\mathrm{EM}}\right)$ retained the ability to survive long-term in the circulation, bone marrow, and lymph nodes [20]. Of note, the $\mathrm{T}_{\mathrm{CM}}$-derived $\mathrm{T}_{\mathrm{E}}$ cells differentiated to both $\mathrm{T}_{\mathrm{CM}}$ and $\mathrm{T}_{\mathrm{EM}}$ phenotypes in vivo and responded efficiently to antigen challenge [20]. This work has recently been extended to human virus-specific $\mathrm{T}$ cells [21].

A major new area reviewed at the meeting was the idea that mature, post-thymic lymphocytes have stem cell-like qualities. Restifo et al. have recently found that Th17-polarized $\mathrm{CD}_{4}^{+} \mathrm{T}$ cells have stem cell-like qualities. Th17 have superior anti-tumour activities than their Th1 counterparts, are resistant to apoptosis and persist long-term after adoptive cell transfer. Most importantly, they have the stem cell-like properties of self-renewal and multipotency [22].

In addition, Gattinoni et al. have identified a subpopulation of circulating $\mathrm{T}$ cells with both naïve and memory T cell properties with a CD45RO-, CCR7+, CD45RA+, CD62L+, CD27+, CD28+ and IL-7R $\alpha+$ phenotype which they have called stem central memory $\mathrm{T}$ (Tscm) cells [23]. These $\mathrm{T} \mathrm{scm}$ cells have greater proliferative potential, longer in vivo survival and are more potent for adoptive cell transfer than naïve, central memory, effector memory or effector $\mathrm{T}$ cells $[23,24]$.

While Tscm cells are potentially very effective in adoptive cellular therapy, very few Tscm cells are present in the circulation. Several laboratories have been investigating methods to reprogram $\mathrm{T}$ cells in order to produce the large quantities of Tscm cells that would be needed for adoptive cell therapy. Wnt signaling/ $\beta$-catenin and mTor signaling pathways have been found to be important in T cell maturation $[25,26]$. The $\mathrm{Wnt} / \beta$-catenin pathway is activated in naïve $T$ cell, but becomes progressively less active as $\mathrm{T}$ cells mature. Because the $\mathrm{Wnt} / \beta$-catenin pathway is important in cancer, a number of drugs are being developed that interact with this pathway. Gattinoni et al. have found that Tscm cells can be efficiently generated in vitro when naïve $\mathrm{T}$ cells are stimulated in the presence of a Wnt pathway activator, TWS119 [23,24]. In the future, it may be possible to use similar methods to generate large quantities of Tscm cells ex vivo for use in adoptive cell therapy coupling TCR or CAR engineering with pharmacological modulation of $\mathrm{T}$ cell differentiation.

\section{Vaccine therapy using long peptides}

An alternative to adoptive transfer of $\mathrm{T}$ cells is vaccination with DCs loaded with short tumor peptides that bind exactly to specific HLA epitopes, however the effectiveness of these therapies have been limited by insufficiently consistent and robust effector $\mathrm{T}$ cell responses. Vaccination with longer tumor peptides (28-35 amino acids) results in more efficient peptide processing and presentation than short peptides. The treatment of 20 women with high grade vulvar intraepithelial neoplasia with 3 subcutaneous Human Papilloma Virus 16 (HPV 16) E6 and E7 synthetic peptide vaccines resulted in clinical responses in 15 of 19 patients at 12 months of follow-up [27]. HPV 16-specific$\mathrm{T}$ cell responses were significantly greater in the group of patients with complete regression of their lesions compared to the non-responders.

\section{NK cells}

Autologous NK cells are being expanded ex vivo by 100 1000 fold and used to treat patients with CLL, colon cancer and renal cell carcinoma (RCC). Patients are first treated with the proteasome inhibitor bortezomib to increase tumor sensitivity to NK cell cytotoxicity mediated by TNF-related apoptosis-inducing ligand (TRAIL) prior to infusion of expanded autologous NK cells with low dose subcutaneous IL-2 administered twice daily for 1 week following infusion [28]. Phase I dose escalation of increasing numbers of adoptively transferred autologous NK cells continues, with 2 infusions of up to a dose of $1 \times 10^{8} \mathrm{NK}$ cells $/ \mathrm{kg}$ having already been established to be safe, with preliminary evidence for anti-tumor effects being observed against tumors such as RCC and CLL.

Allogeneic NK cells are being used to treat hematological malignancies. These allogeneic NK cells protocols 
make use of in vivo expansion by using pretreatment lymphoreduction therapy and post-infusion IL-2 therapy [29]. As an alternative to IL-2, the CITN recently developed a clinical trial to test the safety and efficacy of outpatient IL-15 therapy in order to stimulate NK and CD8 + T cells. IL-15, compared to IL-2, may enhance cellbased immunotherapy as it is hypothesized to have less of an effect on suppressive regulatory T-cells that downregulate NK cell and $\mathrm{T}$ cell function. This may lead to better clinical efficacy and has broad implications for the field of immunotherapy.

\section{Evaluation of biomarkers for adoptive cellular therapies}

A critical part of the treatment of cancer with adoptive cellular therapies is the monitoring of recipients following treatment. Clinical trials of cellular therapies for cancer should include biomarker studies in an integrated, quality, supported, and meta-analyzeable manner [30]. For T cell therapy clinical trials, the biomarker classes assessed should evaluate $\mathrm{T}$ cell presence, biologically relevant phenotypes and functions of the $\mathrm{T}$ cells, $\mathrm{T}$ cell bioactivity, as well as recipient immune responses to the infused $\mathrm{T}$ cells. Numerous approaches can be used to evaluate each of these classes of biomarkers [31]. These principals were recently applied in a clinical trial which treated CLLwith anti-CD19 T cells and this approach provided a remarkable breadth and depth of information concerning $\mathrm{T}$ cell persistence, phenotype, and function $[12,13]$.

\section{Regulatory}

Most clinical studies involving adoptive cellular therapies are conducted under an Investigational New Drug (IND) application. FDA encourages early preparation for critical points in the IND process, such as moving into initial clinical studies and transitioning to pivotal clinical trials. Proper preparation allows for an easier transition, a better designed study, and a higher likelihood of success. FDA staff encourages sponsors and investigators to take advantage of formal meetings, such as pre-IND meetings, and is often willing to speak with sponsors and investigators through direct informal interactions. In addition, numerous FDA websites contain information useful for investigators (http://www.fda.gov/biologicsbloodvaccines/newsevents/ucm232821.htm and http://www.fda.gov/BiologicsBloodVaccines/GuidanceComplianceRegulatoryInformation/OtherRecommendationsforManufacturers/ucm094338.htm).

\section{Conclusions}

The field of adoptive cell therapy is advancing rapidly. Conventional cellular therapies, such as TIL, are becoming more effective and more available. Gene therapy is becoming an important tool in adoptive cell therapy. Autologous lymphocytes are being engineered to express TCRs, CARs and cytokines. T cell subsets with more naïve and stem cell-like characteristics have been shown in pre clinical models to be more effective than unselected populations. In the future combination of adoptive transfer of $\mathrm{T}$ cells and specific vaccination against the cognate antigen can be envisaged to further enhance the effectiveness of treatment.

\section{Author details \\ 'Department of Transfusion Medicine, Clinical Center, NIH, Bethesda, USA. ${ }^{2}$ Fred Hutchinson Cancer Research Center, Seattle, USA. ${ }^{3}$ Fred Hutchinson Cancer Research Center and Cancer Immunotherapy Trials Network (CITN), Seattle, USA. ${ }^{4}$ National Heart, Lung, Blood Institute, NIH, Bethesda, USA. ${ }^{5}$ Surgery Branch, National Cancer Institute, NIH, Bethesda, USA. ${ }^{6}$ Fate Therapeutics, Inc, San Diego, USA. ${ }^{7}$ California Institute of Technology, Pasadena, USA. ${ }^{8}$ University of Pennsylvania, Philadelphia, USA. ${ }^{9}$ Center for Human Immunology, NIH, Bethesda, USA. ${ }^{10}$ University of Minnesota, Minneapolis, USA. "Boston University School of Medicine, Boston, USA. \\ ${ }^{12}$ Center for Regenerative Medicine, NIH, Bethesda, USA. ${ }^{13}$ National Institute of Arthritis and Musculoskeletal and Skin Diseases, Bethesda, USA. ${ }^{14}$ Leiden University Medical Center and Immune System Activation, Leiden, The Netherlands.}

Received: 21 February 2012 Accepted: 15 March 2012

Published: 15 March 2012

\section{References}

1. Rosenberg SA, Yang JC, Sherry RM, Kammula US, Hughes MS, Phan GQ, Citrin DE, Restifo NP, Robbins PF, Wunderlich JR, Morton KE, Laurencot CM, Steinberg SM, White DE, Dudley ME: Durable Complete Responses in Heavily Pretreted Patients with Metastatic Melanoma Using T Cell Transfer Immunotherapy. Clin Cancer Res 2011, 17:4550-4557.

2. Dudley ME, Wunderlich JR, Shelton TE, Even J, Rosenberg SA: Generation of tumor-infiltrating lymphocyte cultures for use in adoptive transfer therapy for melanoma patients. J Immunother 2003, 26:332-342.

3. Dudley ME, Gross CA, Langhan MM, Garcia MR, Sherry RM, Yang JC, Phan GQ, Kammula US, Hughes MS, Citrin DE, Restifo NP, Wunderlich JR, Prieto PA, Hong JJ, Langan RC, Zlott DA, Morton KE, White DE, Laurencot CM, Rosenberg SA: CD8+ enriched "young" tumor infiltrating lymphocytes can mediate regression of metastatic melanoma. Clin Cancer Res 2010, 16:6122-6131.

4. Tran CA, Burton L, Russom D, Wagner JR, Jensen MC, Forman SJ, DiGiusto DL: Manufacturing of large numbers of patient-specific T cells for adoptive immunotherapy: an approach to improving product safety, composition, and production capacity. J Immunother 2007, 30:644-654.

5. Jin J, Sabatino M, Somerville R, Wilson JR, Dudley ME, Stroncek DF, Rosenberg SA: Simplified Method of the Growth of Human Tumor Infiltrating Lymphocytes in Gas-permeable Flasks to numbers Needed for Patient Treatment. J Immunother 2012, 35:283-292.

6. Park TS, Rosenberg SA, Morgan RA: Treating cancer with genetically engineered T cells. Trends Biotechnol 2011, 29:550-557.

7. Morgan RA, Dudley ME, Wunderlich JR, Hughes MS, Yang JC, Sherry RM, Royal RE, Topalian SL, Kammula US, Restifo NP, Zheng Z, Nahvi A, de Vries CR, Rogers-Freezer LJ, Mavroukakis SA, Rosenberg SA: Cancer regression in patients after transfer of genetically engineered lymphocytes. Science 2006, 314:126-129.

8. Johnson LA, Morgan RA, Dudley ME, Cassard L, Yang JC, Hughes MS, Kammula US, Royal RE, Sherry RM, Wunderlich JR, Lee CC, Restifo NP, Schwarz SL, Cogdill AP, Bishop RJ, Kim H, Brewer CC, Rudy SF, VanWaes C, Davis JL, Mathur A, Ripley RT, Nathan DA, Laurencot CM, Rosenberg SA: Gene therapy with human and mouse T-cell receptors mediates cancer regression and targets normal tissues expressing cognate antigen. Blood 2009, 114:535-546,

9. Robbins PF, Morgan RA, Feldman SA, Yang JC, Sherry RM, Dudley ME, Wunderlich JR, Nahvi AV, Helman L, Mackall CL, Kammula US, Hughes MS, 
Restifo NP, Raffeld M, Lee CC, Levy CL, Li YF, El-Gamil M, Schwarz SL, Laurencot C, Rosenberg SA: Tumor regression in patients with metastatic synovial cell sarcoma and melanoma using genetically engineered lymphocytes reactive with NY-ESO-1. J Clin Oncol 2011, 29:917-924.

10. Kochenderfer JN, Wilson WH, Janik JE, Dudley ME, Stetler-Stevenson M, Feldman SA, Maric I, Raffeld M, Nathan DA, Lanier BJ, Morgan RA, Rosenberg SA: Eradication of B-lineage cells and regression of lymphoma in a patient treated with autologous $\mathrm{T}$ cells genetically engineered to recognize CD19. Blood 2010, 116:4099-4102.

11. Kochenderfer JN, Dudley ME, Feldman SA, Wilson WH, Spaner DE, Maric I, Stetler-Stevenson M, Phan GQ, Hughes MS, Sherry RM, Yang JC, Kammula US, Devillier L, Carpenter R, Nathan DA, Morgan RA, Laurencot C, Rosenberg SA: B-cell depletion and remissions of malignancy along with cytokine-associated toxicity in a clinical trial of anti-CD19 chimericantigen-receptor-transduced T cells. Blood 2011.

12. Porter $\mathrm{DL}$, Levine $\mathrm{BL}$, Kalos $\mathrm{M}$, Bagg $\mathrm{A}$, June $\mathrm{CH}$ : Chimeric antigen receptor-modified T cells in chronic lymphoid leukemia. N Engl J Med 2011, 365:725-733

13. Kalos M, Levine BL, Porter DL, Katz S, Grupp SA, Bagg A, June CH: T cells with chimeric antigen receptors have potent antitumor effects and can establish memory in patients with advanced leukemia. Sci Trans/ Med 2011, 3:95ra73.

14. Song $D G$, Ye Q, Carpenito C, Poussin $M$, Wang LP, Ji C, Figini $M$, June $C H$, Coukos G, Powell DJ Jr: In vivo persistence, tumor localization, and antitumor activity of CAR-engineered T cells is enhanced by costimulatory signaling through CD137 (4-1BB). Cancer Res 2011, 71:4617-4627.

15. Powell DJ Jr, Dudley ME, Robbins PF, Rosenberg SA: Transition of latestage effector $T$ cells to $C D 27+C D 28+$ tumor-reactive effector memory T cells in humans after adoptive cell transfer therapy. Blood 2005, 105:241-250.

16. Takahashi K, Yamanaka S: Induction of pluripotent stem cells from mouse embryonic and adult fibroblast cultures by defined factors. Cell 2006, 126:663-676.

17. Mostoslavsky G: Concise review: the magic act of generating induced pluripotent stem cells: many rabbits in the hat. Stem Cells 2012, 30:28-32.

18. Somers A, Jean JC, Sommer CA, Omari A, Ford CC, Mills JA, Ying L, Sommer AG, Jean JM, Smith BW, Lafyatis R, Demierre MF, Weiss DJ, French DL, Gadue P, Murphy GJ, Mostoslavsky G, Kotton DN: Generation of transgene-free lung disease-specific human induced pluripotent stem cells using a single excisable lentiviral stem cell cassette. Stem Cells 2010, 28:1728-1740.

19. Staerk J, Dawlaty MM, Gao Q, Maetzel D, Hanna J, Sommer CA, Mostoslavsky G, Jaenisch R: Reprogramming of human peripheral blood cells to induced pluripotent stem cells. Cell Stem Cell 2010, 7:20-24.

20. Berger C, Jensen MC, Lansdorp PM, Gough M, Elliott C, Riddell SR: Adoptive transfer of effector CD8+ T cells derived from central memory cells establishes persistent T cell memory in primates. J Clin Invest 2008, 118:294-305.

21. Wang X, Berger C, Wong CW, Forman SJ, Riddell SR, Jensen MC: Engraftment of human central memory-derived effector CD8+ T cells in immunodeficient mice. Blood 2011, 117:1888-1898.

22. Muranski P, Borman ZA, Kerkar SP, Klebanoff CA, Ji Y, Sanchez-Perez L, Sukumar M, Reger RN, Yu Z, Kern SJ, Roychoudhuri R, Ferreyra GA, Shen W, Durum SK, Feigenbaum L, Palmer DC, Antony PA, Chan CC, Laurence A, Danner RL, Gattinoni L, Restifo NP: Th17 cells are long lived and retain a stem cell-like molecular signature. Immunity 2011, 35:972-985.

23. Gattinoni L, Lugli E, Ji Y, Pos Z, Paulos CM, Quigley MF, Almeida JR, Gostick E, Yu Z, Carpenito C, Wang E, Douek DC, Price DA, June CH, Marincola FM, Roederer M, Restifo NP: A human memory T cell subset with stem cell-like properties. Nat Med 2011, 17:1290-1297.

24. Gattinoni L, Zhong XS, Palmer DC, Ji Y, Hinrichs CS, Yu Z, Wrzesinski C, Boni A, Cassard L, Garvin LM, Paulos CM, Muranski P, Restifo NP: Wnt signaling arrests effector T cell differentiation and generates CD8+ memory stem cells. Nat Med 2009, 15:808-813.

25. Gattinoni L, Klebanoff CA, Restifo NP: Pharmacologic induction of CD8+ T cell memory: better living through chemistry. Sci Trans/ Med 2009, 1:11ps12.

26. Gattinoni L, Ji Y, Restifo NP: Wnt/beta-catenin signaling in T-cell immunity and cancer immunotherapy. Clin Cancer Res 2010, 16:4695-4701.
27. Kenter GG, Welters MJ, Valentijn AR, Lowik MJ, Berends-van der Meer DM, Vloon AP, Essahsah F, Fathers LM, Offringa R, Drijfhout JW, Wafelman AR, Oostendorp J, Fleuren GJ, van der Burg SH, Melief CJ: Vaccination against HPV-16 oncoproteins for vulvar intraepithelial neoplasia. N Engl J Med 2009, 361:1838-1847.

28. Lundqvist A, Berg M, Smith A, Childs RW: Bortezomib Treatment to Potentiate the Anti-tumor Immunity of Ex-vivo Expanded Adoptively Infused Autologous Natural Killer Cells. J Cancer 2011, 2:383-385.

29. Miller JS, Soignier Y, Panoskaltsis-Mortari A, McNearney SA, Yun GH, Fautsch SK, McKenna D, Le C, DeFor TE, Burns LJ, Orchard PJ, Blazar BR, Wagner JE, Slungaard A, Weisdorf DJ, Okazaki IJ, McGlave PB: Successful adoptive transfer and in vivo expansion of human haploidentical NK cells in patients with cancer. Blood 2005, 105:3051-3057.

30. Kalos M: An integrative paradigm to impart quality to correlative science. J Trans/ Med 2010, 8:26.

31. Kalos M: Biomarkers in T cell therapy clinical trials. J Trans/ Med 2011, 9:138.

doi:10.1186/1479-5876-10-48

Cite this article as: Stroncek et al:: New directions in cellular therapy of cancer: a summary of the summit on cellular therapy for cancer. Journal of Translational Medicine 2012 10:48.

\section{Submit your next manuscript to BioMed Central and take full advantage of:}

- Convenient online submission

- Thorough peer review

- No space constraints or color figure charges

- Immediate publication on acceptance

- Inclusion in PubMed, CAS, Scopus and Google Scholar

- Research which is freely available for redistribution

Submit your manuscript at www.biomedcentral.com/submit
Ciomed Central 